\title{
Present Status of Fruit Fly Bactrocera carambolae Drew \& Hancock (Diptera: Tephritidae) in Bali Island, Indonesia
}

\author{
I Putu Sudiarta ${ }^{1 *}$, Febri Eka Wijayanti ${ }^{2}$, I Gede Rai M Temaja ${ }^{1}$, Gusti N A S Wirya ${ }^{1}$, \\ Ketut Sumiartha ${ }^{1}$, Dewa G W Selangga ${ }^{1}$ \\ ${ }^{1}$ Faculty of Agriculture, Udayana University, Denpasar, Bali 80234, Indonesia \\ ${ }^{2}$ Agricultural Quarantine Agency of Denpasar, Bali, Indonesia \\ Corresponding Author. E-mail: putusudiarta@unud.ac.id
}

\begin{abstract}
Bactrocera carambolae, commonly known as the fruit fly, has been reported as a prominent pest for fruits and vegetables around the world. It has been recorded to infect hosts from a wide range of families and was shown to spread worldwide including Indonesia. The identification of species is needed such that clear information on distribution of the species can be obtained. The combination of analysis through morphology and molecular approaches provide an accurate method of identification. The identification of DNA-based barcode for fruit flies using mitochondrial cytochrome oxidase I gene (mtCOI) was conducted. The result of DNA extraction was amplified using PCR with general primers mtCOI Fruit Fly MT-CO1-F as forward primer and $\mathrm{HCO}$ as the reverse primer. A $690 \mathrm{bp}$ amplicon of the fruit flies mtCOI gene was obtained. Bactrocera carambolae is the species identified from 9 regencies in Bali Island based on morphology diagnosis and sequence analysis of fruit flies.
\end{abstract}

Keywords: fruit fly, Bactocera carambolae, morphology diagnosis, sequence analysis, Bali island

\section{INTRODUCTION}

Fruit flies cause damage to 150 species of fruit and vegetable plants in both the tropics and subtropics $[1,2]$. Of the several genera in the family Tephritidae, the genus Bactrocera is one of the largest genus identified and consist of 500 species divided into 28 subgenus [3, 4]. According to Drew and Hancock, the Bactocera subgenus is divided into 4 groups based on their morphology, namely: Bactrocera, Queenslandacus, Zeugodacus, and Melanodacus. Two of these fruit fly species are $B$. carambolae and B. papayae, both of which are members of the Bactrocera dorsalis (Hendel) complex and have similar morphological characteristics that are difficult to distinguish from body size, wing and abdominal patterns $[5,6]$. In order to properly distinguish the two species a molecular identification approach, as well as the distribution of species in Bali, is needed.

Molecular identification has been utilized for improving the accuracy of information from morphological characteristics due to its higher efficiency in reproducibility compared to morphological-based identification. DNA barcoding has gradually been verified as an effective tool for identifying species in a wide range of taxonomic groups [7]. DNA barcoding using Gen Mitochondrial Cytochrome Oxidase Subunit I (mtCO1) has been utilized for identification of fruit flies. The MTCOI barcode sequences for the diagnosis of fruit flies using 1426 sequences from 73 species of Bactrocera distributed worldwide was reported by Jiang et al. [7]. In this study, the combination of morphological diagnosis and DNA barcoding using mtCOI gene was performed to reconfirm both species. The present condition of fruit flies is critical to understand its distribution and its controlling methods [8].

\subsection{Materials and Methods}

\subsubsection{Fruit fly collection}

The method of trapping fruit fly was conducted based on pests and diseases survey protocol of Agricultural Quarantine Agency. The trapping location was designed in nine regencies (Denpasar, Badung, Gianyar, Tabanan, Klungkung, Karangasem, Bangli, Jembrana, and Buleleng) of Bali Island using Steiner Trap with attractant Methyl eugenol. The trap was placed on starfruit or guava as the host plant of Bactrocera carambolae. The fruit fly sample was collected a week after traps were set up.

\subsubsection{Morphological identification}

The morphological diagnosis was conducted based on "The Australian Handbook for the Identification of Fruit 
Flies" [9]. Key features used for the morphological diagnosis of adult fruit flies include: wing morphology and infuscation, presence or absence of various setae, and relative setal size. We do not use chaetotaxy/ setal taxonomy, since it is not as important in this group. In addition, overall colour and colour patterning, as well as presence, shape and colour of thoracic vittae are also used for identification. [9].

\subsubsection{Molecular Identification}

\subsubsection{DNA extraction and mtCOI gen amplification.}

Qiagen DNeasy® (Qiagen, Hilden, Germany) Blood and Tissue kit was used to extract the DNA of fruit flies. The result of DNA extraction was amplified using PCR with general primers mtCOI Fruit Fly MT-CO1-F (FFMTCO1-F)5'-GGA GCA TTA ATY GGR GAY G-3' as forward primer and HCO 5'-TAA ACT TCA GGG TGA CCA AAA ATC A-3' as reverse primer. The PCR thermal cycle program consisted of initial denaturing at $94{ }^{\circ} \mathrm{C}$ for 2 min, followed by 40 cycles of denaturing at $94{ }^{\circ} \mathrm{C}$ for 30 $\mathrm{s}$, annealing at $52^{\circ} \mathrm{C}$ for $30 \mathrm{~s}$ and extension at $72{ }^{\circ} \mathrm{C}$ for 1 min with final extension at $72{ }^{\circ} \mathrm{C}$ for $7 \mathrm{~min}$ and finally holding at $4{ }^{\circ} \mathrm{C}$ until analysed [9].

\subsubsection{Sequencing analysis}

PCR product of fruit flies were analysed in First Base Laboratory, Malaysia for sequencing. The nucleotide sequence was used to search similarity in GeneBank using the program Basic Local Alignment Tool (BLAST) in the European Bioinformatic Institute (EBI) (www.ebi.ac.uk). The nucleotide sequence of fruit flies were aligned in order to obtain a homolog similarity score using the program ClustalW.

\subsection{Our Contribution}

This paper provides information about the identification of B. carambolae with morphological and molecular characters. The identification is to ensure the species of $B$. carambolae which has similarities with $B$. papayae. This research provides information about the distribution of $B$. carambolae throughout Bali. Those data can be used as preliminary data for quarantine and control measures.

\subsection{Paper Structure}

The stages of this research are structured as follows: stage 1 is describing the results of morphological of $B$. carambolae. Stage 2 is molecular identification of $B$. carambolae using a sequence analysis approach in the form of sequence homology.

\section{RESULTS AND DISCUSSION}

\subsection{Morphological Diagnosis}

All samples from the traps (on starfruit and guava plant) in all regencies of Bali Island were collected and used for morphological and molecular analysis. Coordinate of each regency compiled on Table 1.

Table 1 Coordinate of each regency

\begin{tabular}{|c|l|l|}
\hline No. & Regency & Location site \\
\hline 1. & Denpasar Regency & $\begin{array}{l}\mathrm{E} 115^{\circ} .25 .8825- \\
\mathrm{S} 8^{\circ} 65.771\end{array}$ \\
\hline 2. & Bandung Regency & $\begin{array}{l}\mathrm{E} 115^{\circ} .190308- \\
\mathrm{S} 8^{\circ} .546831\end{array}$ \\
\hline 3. & Gianyar Regency & $\begin{array}{l}\mathrm{S} 8^{\circ} .413290 \\
\mathrm{E} 115^{\circ} .284496\end{array}$ \\
\hline 4. & Tabanan Regency & $\begin{array}{l}\mathrm{S} 8^{\circ} .408556- \\
\mathrm{E} 115^{\circ} .145202\end{array}$ \\
\hline 5. & Klungkung Regency & $\mathrm{S}^{\circ} .487356-$ \\
& & $\mathrm{E} 115^{\circ} .376593$ \\
\hline 6. & Karangasem Regency & $\mathrm{S}^{\circ} .502614-$ \\
& & $\mathrm{E} 115^{\circ} .608320$ \\
\hline 7. & Bangli Regency & $\mathrm{S} 8^{\circ} .422266-$ \\
& & $\mathrm{E} 115^{\circ} .348018$ \\
\hline 8. & Jembrana Regency & $\mathrm{S}^{\circ} .2301$ \\
& & $\mathrm{E} 114.5480^{\circ}$ \\
\hline 9. & Buleleng Regency & $\mathrm{S} 08^{\circ} 10.049$ \\
& & $\mathrm{E} 114^{\circ} 30.291$ \\
\hline
\end{tabular}

The focus of identification is on the face (cephalo), thorax, wings, and abdomen. The result is described below: face fulvous with a pair of medium sized oval black spots; scutum dull black with brown behind lateral postsutural vittae, around mesonotal suture and inside postpronotal lobes; postpronotal lobes and notopleura yellow; mesopleural stripe reaching midway between anterior margin of notopleuron and anterior $\mathrm{npl}$. seta dorsally; two broad parallel sided lateral postsutural vittae ending at or behind ia. seta; medial postsutural vitta absent; scutellum yellow; legs with femora fulvous with a large elongate oval dark fuscous to black preapical spot on outer surfaces of fore femora in some specimens, tibiae dark fuscous (except mid tibiae paler apically); wings with cells bc and c colourless, microtrichia in outer corner of cell c only, a narrow fuscous costal band slightly overlapping $\mathrm{R}_{2}+3$ and expanding slightly beyond apex of $\mathrm{R} 2+3$ across apex of $\mathrm{R} 4+5$, a narrow fuscous anal streak; supernumerary lobe of medium development; abdominal terga III-V orange-brown with a ' $\mathrm{T}$ ' pattern consisting of a narrow transverse black band across anterior margin of 
The morphological characteristic of fruit flies from nine regencies of Bali Island were confirmed based on the handbook. The identification method based on the morphological diagnosis indicated that the samples collected from nine regencies of Bali Island is $B$. carambolae (Figures 1-9). tergum III and widening to cover lateral margins, a medium width medial longitudinal black band over all three terga, anterolateral corners of terga IV dark fuscous to black and rectangular in shape and anterolateral corners of tergum $\mathrm{V}$ dark fuscous, a pair of oval orange-brown shining spots on tergum $\mathrm{V}$; abdominal sterna dark coloured; posterial lobe of male surstylus short; female with aculeus tip needle shaped (pers. comm. Drew 2010).

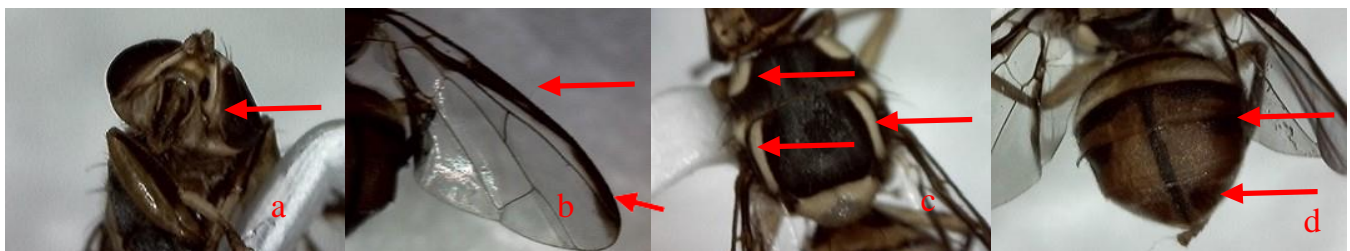

Figure 1 Morphological identification of B. carambolae from Denpasar Regency on starfruit: (a) spot of face, (b) wings pattern, (c) thorax, (d) abdomen
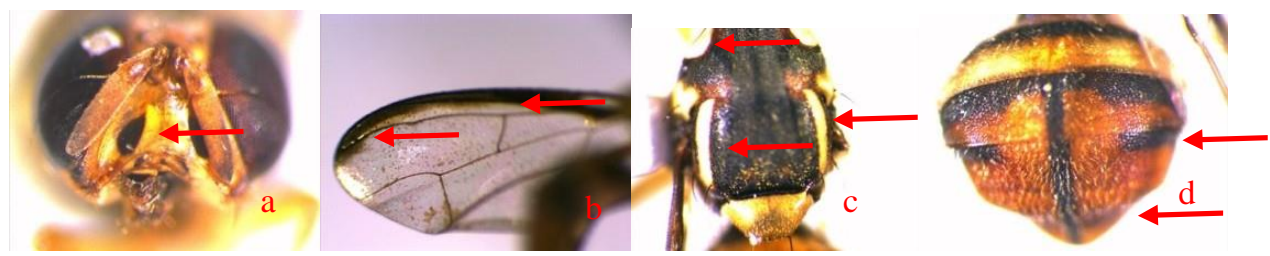

Figure 2 Morphological identification of B. carambolae from Bandung Regency on starfruit: (a) spot of face, (b) wings pattern, (c) thorax, (d) abdomen

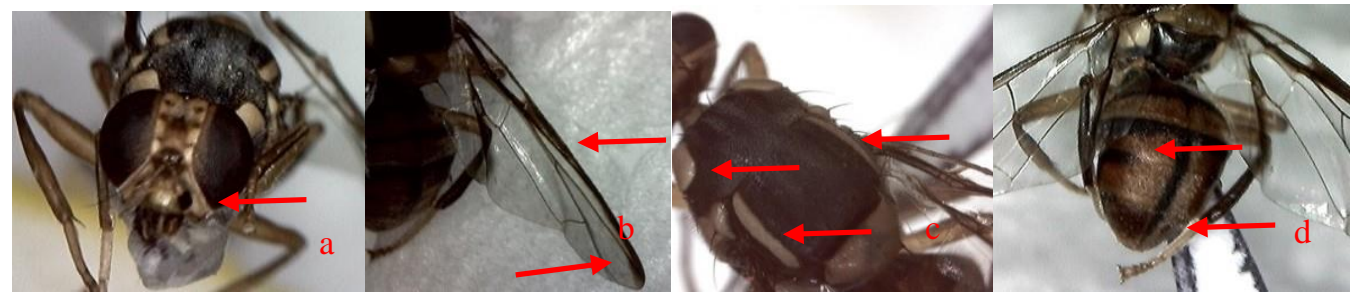

Figure 3 Morphological identification of B. carambolae from Gianyar Regency on starfruit: (a) spot of face, (b) wings pattern, (c) thorax, (d) abdomen
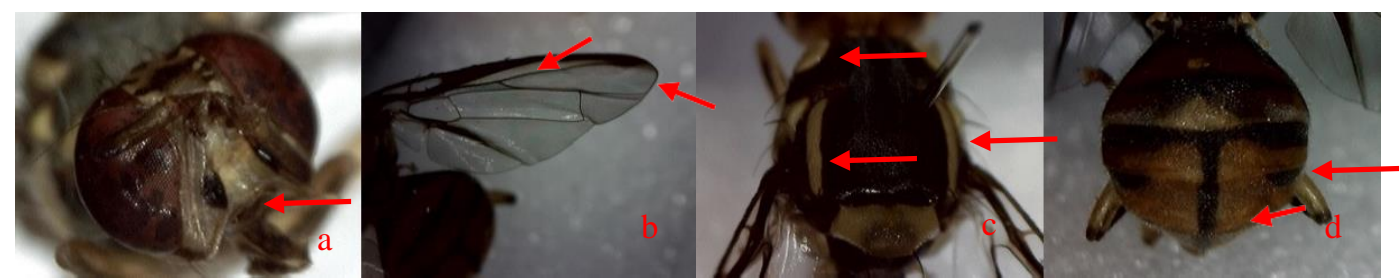

Figure 4 Morphological identification of B. carambolae from Tabanan Regency on starfruit: (a) spot of face, (b) wings pattern, (c) thorax, (d) abdomen 

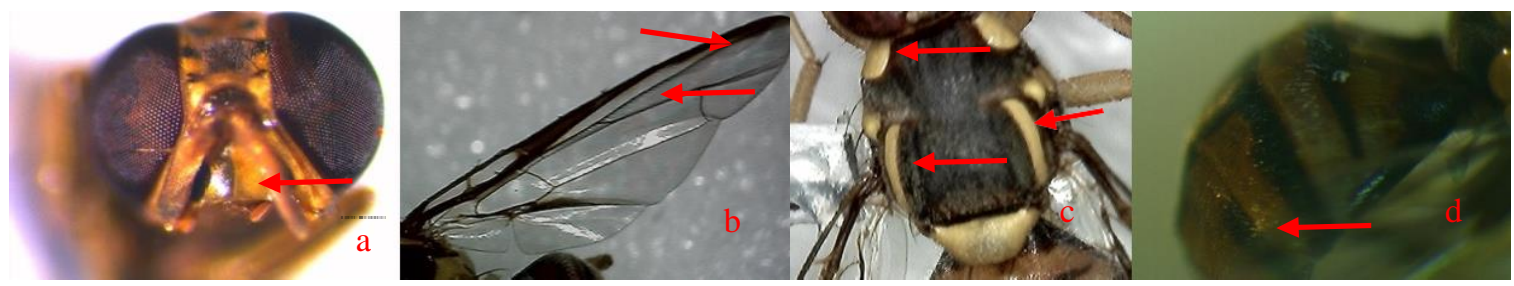

Figure 5 Morphological identification of B. carambolae from Klungkung Regency on starfruit: (a) spot of face, (b) wings pattern, (c) thorax, (d) abdomen

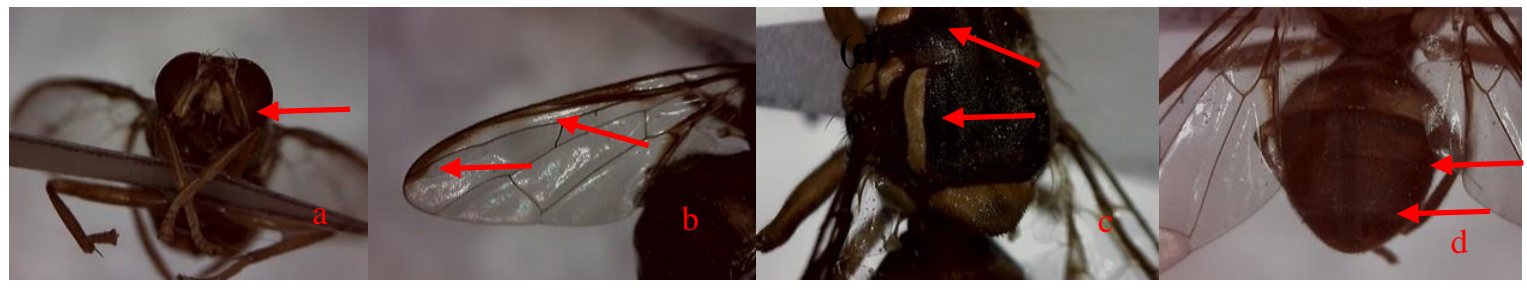

Figure 6 Morphological identification of B. carambolae from Karangasem Regency on guava: (a) spot of face, (b) wings pattern, (c) thorax, (d) abdomen

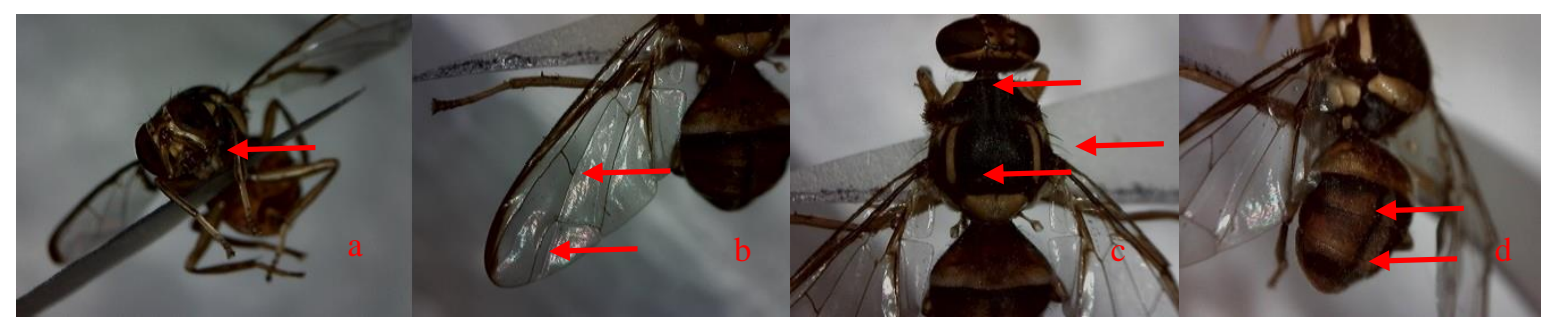

Figure 7 Morphological identification of B. carambolae from Bangli Regency on starfruit: (a) spot of face, (b) wings pattern, (c), thorax, (d) abdomen
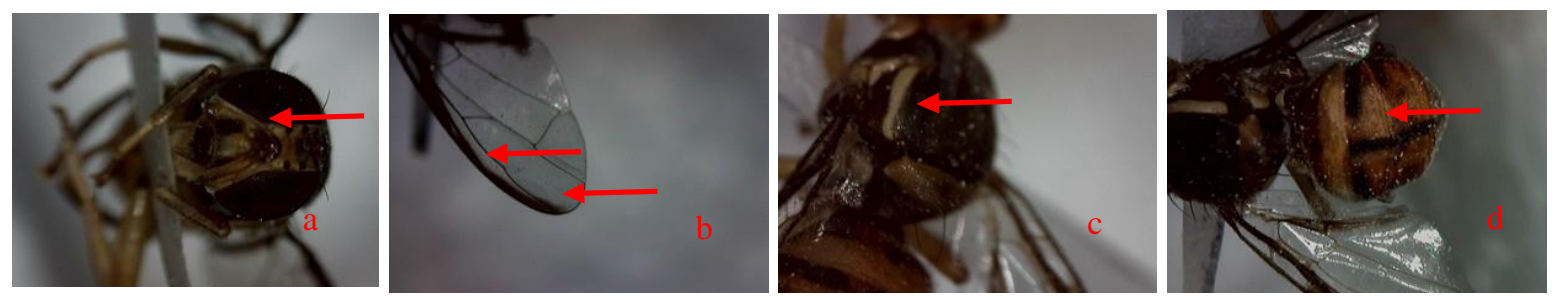

Figure 8 Morphological identification of B. carambolae from Jembrana Regency on starfruit: (a) spot of face, (b) wings pattern, (c) thorax, (d) abdomen

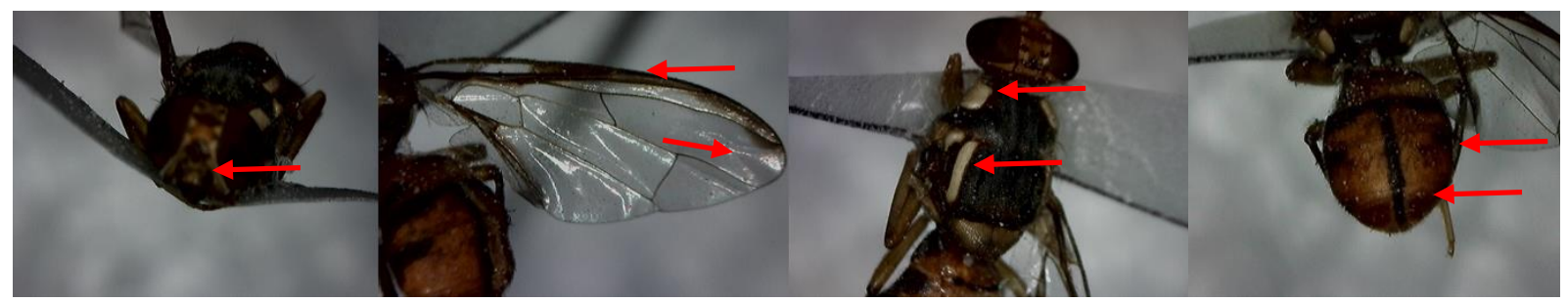

Figure 9 Morphological identification of B. carambolae from Buleleng Regency (S 08 $\left.10.049-\mathrm{E} 114^{\circ} 30.291\right)$ on starfruit: (a) spot of face, (b) wings pattern, (c) thorax, (d) abdomen 


\subsubsection{Sequence homology}

The homology $(\%)$ sequence of mtCOI gen of fruit

\subsubsection{DNA Amplification}

The PCR amplification using general primers mtCOI Fruit Fly MT-CO1-F as forward primer and $\mathrm{HCO}$ as reverse primer successfully amplified $690 \mathrm{bp}$ of mtCOI gene. All PCR products were utilized for sequence analysis, including sequence homology (Table 2) and alignment (data not show) of all samples collected in the regencies of Bali Island.

flies from all regencies of Bali Island were analysed and high similarity of all fruit flies were recorded (99\%) Table 2. The data indicated that all fruit flies originated from nine regencies of Bali Island is $B$. carambolae. The sequence analysis was performed to support the morphological diagnosis of B. carambolae. In addition, other species of fruit flies were compared to the nine samples obtained in Bali Island and was found to have very low homology with JX559679 B. umbrosa, M95816 C. capitate, and KT864760 B. papayae (Table 2).

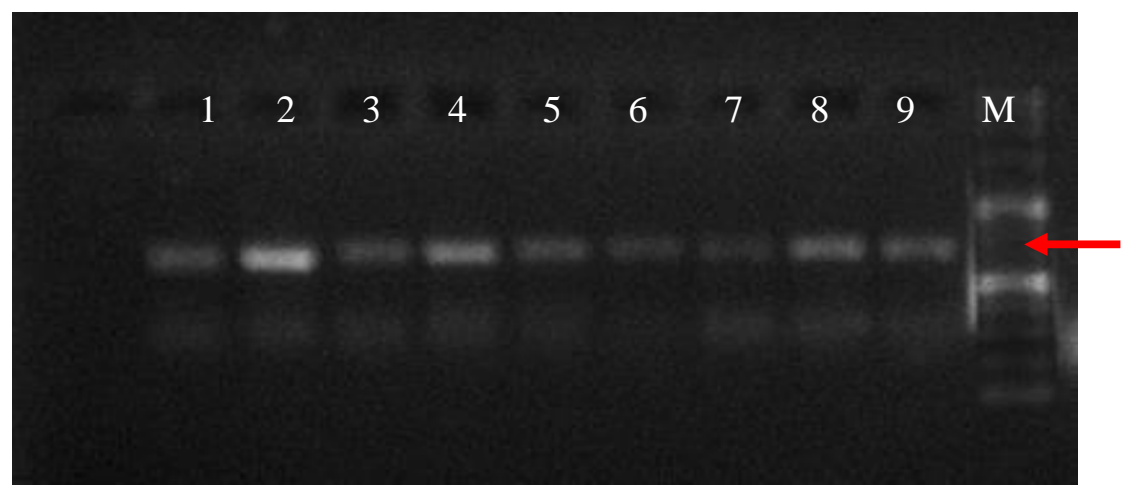

Figure 10 Amplification of fruit flies nucleotide of mtCOI from all regencies of Bali Island with 690 bp primers pair FFCOI-F and HCO: (1) Denpasar, (2) Bandung, (3) Gianyar, (4) Tabanan, (5) Klungkung, (6) Karangasem, (7) Bangli, (8) Jembrana, (9) Buleleng, M: 100 bp marker (Thermo scientific)

Table 2 The homology (\%) sequence of mtCOI gen of fruit flies from all regencies of Bali Island compared with other fruit flies sequence in GenBank.

\begin{tabular}{|c|c|c|c|c|c|c|c|c|c|c|c|c|}
\hline Sequence & 1 & 2 & 3 & 4 & 5 & 6 & 7 & 8 & 9 & 10 & 11 & 12 \\
\hline 1. Denpasar & ID & & & & & & & & & & & \\
\hline 2. Badung & 99.4 & ID & & & & & & & & & & \\
\hline 3. Gianyar & 99.3 & 99.1 & ID & & & & & & & & & \\
\hline 4. Tabanan & 99.4 & 99.3 & 99.8 & ID & & & & & & & & \\
\hline 5. Klungkung & 99.6 & 99.8 & 99.3 & 99.4 & ID & & & & & & & \\
\hline 6. Karangasem & 99.6 & 99.8 & 99.3 & 99.4 & 100 & ID & & & & & & \\
\hline 7. Bangli & 99.3 & 99.4 & 98.9 & 99.1 & 99.6 & 99.6 & ID & & & & & \\
\hline 8. Jembrana & 99.4 & 99.3 & 99.4 & 99.3 & 99.4 & 99.4 & 99.1 & ID & & & & \\
\hline 9. Buleleng & 99.6 & 99.1 & 98.9 & 99.1 & 99.3 & 99.3 & 99.3 & 99.1 & ID & & & \\
\hline $\begin{array}{l}\text { 10. JX559670 B. } \\
\text { umbrosa }\end{array}$ & 24.0 & 23.8 & 24.0 & 23.8 & 23.6 & 23.6 & 24.0 & 24.0 & 24.1 & ID & & \\
\hline $\begin{array}{l}\text { 11. M95816 C. } \\
\text { capitata }\end{array}$ & 26.7 & 26.4 & 26.9 & 26.9 & 26.5 & 26.5 & 26.7 & 26.7 & 26.9 & 35.1 & ID & \\
\hline $\begin{array}{l}\text { 12. KT } 864760 B . \\
\text { papayae }\end{array}$ & 27.4 & 27.2 & 27.2 & 27.2 & 27.1 & 27.1 & 27.2 & 27.4 & 27.4 & 87.2 & 37.2 & ID \\
\hline
\end{tabular}


[8] F. Massebo, Z. Tefera, Status of Bactrocera invadens (Diptera: Tephritidae) in mangoproducing areas of Arba Minch, Southwestern Ethiopia, J. Insect Sci. 15 (1) (2015) 3. DOI: https://doi.org/10.1093/jise sa/ieu1 66

[9] Plant Health Australia, The Australian handbook for the identification of fruit flies. Version 1.0. Plant Health Australia. Canberra, ACT, 2011

The current research was funded by collaborating between Magister of Agriculture Biotechnology, Faculty of Agriculture Udayana University and Agricultural Quarantine Agency Denpasar.

\section{REFERENCES}

[1] A.V. Alyoklin, R. H. Messing, J.J. Duan, Visual and olfactory stimuli and fruit maturity affect trap captures of oriental fruit flies (Diptera: Tephritidae), J. Econ. Entomol. 93 (3) (2000) 664669. DOI: https://doi.org/10.1603/0022-049393.3.644

[2] F. H. Haramoto, H. A. Bess, Recent Studies on the abundance of the oriental and Mediterranean fruit flies and the status of their parasite. Proceeding Hawai. Entomolol. Soc. 20 (3) (1970) 551- 556

[3] R. A. I. Drew, G. H. S. Hooper, M. A. Bateman, Economic fruit flies of the South Pacific Region, 2nd edition, Department of Primary Industries, Brisbane, Queensland, 1982

[4] R. A. I. Drew, D, L, Hancock, Phylogeny of the tribe Dacini (Dacinae) based on morphological, distributional, and biological data. In: Aluja, M., Norrbom, A.L. (Eds.), fruit flies (Tephritidae): phylogeny and evolution of behavior, CRC Press, Boca Raton, FL, 2000, pp. 491-504

[5] T. H. Chua, Y. V. Chong, S. H. Lim, Species determination of Malaysian bactrocera pests using PCR-RFLP analyses (Diptera: Tephritidae). Pest Manag. Sci. (2009) 379-384. DOI: https://doi.org/10. 1002/ps.1886

[6] T. Ebina, K. Ohto, 2006 Morphological characters and PCR-RFLP markers in the interspecific hybrids between Bactrocera carambolae and $B$. papayae of the $B$. dorsalis species complex (Diptera: Tephritidae), Research Bulletin of the Plant Protection Service Japan 42 (2006) 23-34

[7] F. Jiang, Q. Jin, L. Liang, A.B. Zhang, Z. H. Li, Existences of species complex largely reduced barcoding success for invasive species of Tephritidae: a case study in Bactrocera spp. Mol. Ecol. Resour. (2014). DOI:https://doi.org/ $10.1111 / 1755-0998.12259$ 